JSS $2 / 88$

Selected

Determinants

of Interpersonal

Communication

in Negotiation -

between Openness

and Manipulation

Submitted

02/2015

Accepted for

publication

03/2015

Selected Determinants

of Interpersonal

Communication in

Negotiation - between

Openness and

Manipulation

Tarpasmeninès komunikacijos

derybose veiksniai - tarp atvirumo

ir manipuliacijos

\title{
Elżbieta Kowalczyk
}

Poznań University of Economics

Aleja Niepodległości 10, 61-875 Poznań, Poland

\section{Pawet Kleka}

Adam Mickiewicz University

ul. Wieniawskiego 1, 60-712 Poznań, Poland

$\Gamma$

crossef http://dx.doi.org/10.5755/j01.ss.88.2.12740

\section{Abstract}

This theoretical and empirical article is dedicated to issues concerning communication in negotiation and the analysis of selected determinants. The authors have assumed that communication has two dimensions: one is based on open communication and the other on manipulative techniques. The research problem of the empirical study conducted by the authors was to establish what factors determine the use of these two dimensions of communication. Drawing on literature studies, they empirically examined such selected factors as social value orientation, experience and satisfaction with negotiation. This problem has been verified by an empirical study conducted in a group of 313 respondents. The main conclusions of the study refer to a correlation between the use of manipulation techniques in negotiation and a proself orientation, experience and the post-negotiation dissonance effect. In contrast, open communication is correlated with a prosocial orientation and a greater satisfaction with negotiation.

vol. 2 / No. 88 / 2015

pp. 8-23

DOI 10.5755/j01.ss.88.2.12740

(c) Kaunas University of Technology 
The starting point for the considerations in this article is the assumption that negotiation is a form of feedback-based communication that leads to a decision (Fisher, Ury and Patton 1994). Such communication can take two forms: open or based on manipulative techniques. Both researchers and practitioners often point to principles that guide open communication as the conditions of effective negotiations, being in harmony with oneself and care for relationships (Lewicki, Suanders and Barry, 2006; Chełapa, 2000; Donaldson and Donaldson, 1999; Fleck, Volkema, Pereira, Levy and Vaccari, 2014). The second form of communication refers to negotiation techniques often discussed in the context of ethics (e.g. Lewicki and Robinson, 1998) or the extent of their use (Fleck et al., 2014; Jastrzębska-Smolaga, 2007; Kowalczyk, 2011; Lewicki and Hanke, 2012). The purpose of the empirical study conducted by the authors was to find out what factors determine the use of the aforementioned modes of communication.

The article consists of three parts. It first discusses the problem of communication. Drawing on the considerations and using factor analysis, the authors have developed a reliable, two-dimensional tool that explores the use of open communication $(\mathrm{OC})$ and a tendency to resort to manipulative techniques (MT).

The second part discusses social value orientation, experience and satisfaction with negotiations as determinants of the two modes of communication. Social value orientation can be divided into proself and prosocial orientations (Grzelak, 2004), both of which determine negotiation behaviour (Lewicki et al., 2006). This has allowed formulating the first research hypothesis that assumes a relationship between the form of communication and social value orientation. In turn, experience is a factor that improves negotiation skills (Kowalczyk, 2001). At this point another hypothesis has been formulated assuming a relationship between the frequency of negotiations and the type of communication during negotiations. Satisfaction with negotiation was the last of the analysed determinants. The literature highlights the importance of satisfaction which can become the basis for qualitative assessment of the resulting agreement (Olvier, Balkirshnan and Barry, 1994), and is additionally dependent on negotiation measures (Winch and Winch, 2005). This has become the basis for the final hypotheses concerning the relationship between the types of communication and satisfaction reached by negotiators.

The third part presents the results of the authors' survey, conducted in a group of 313 respondents through an internet portal ebadania.pl. Social orientation was measured by using two questions in which the surveyed declared their negotiation goals. Drawing on their responses, two groups of respondents were distinguished: 236 subjects with a prosocial orientation and 52 subjects with a proself orientation. While experience was measured based on the frequency of professional and non-professional negotiations, satisfaction was estimated in three dimensions: achieved negotiation goals, relationships and overall satisfaction. The varied statistical analysis has allowed us to verify the research hypotheses and confirm the key assumption about the relationship between the type of communication and the above-described determinants. Based on empirical findings, the concept of the postnegotiation dissonance effect has been suggested, which explains the lack of relationship between communication based on manipulative techniques and satisfaction with negotiations.

There is a wide range of definitions of negotiation. However, this study is based on the one coined by Fisher, Ury and Patton (1994), who claim that negotiation is a process of communication and decision-making in which the parties seek to reach an agreement on some common or reciprocal interest. It is worth noting that an understanding of negotiation as communication is present in many definitions and is extremely important from the point of view of further consideration (e.g., Rządca and Wujec, 1998; Nęcki, 2000; Nierenberg, 1994), while communication is also understood as a medium of negotiation (e.g., Negocjacje, 2003).

\section{Introduction}


Negotiation is a key element of professional success and its effective use depends on many factors. The importance of negotiation was already noticed in the early 1970s by Mintzberg, who claimed that managers spend most of their time at work negotiating a range of very different issues. Negotiation may be conducted in two ways that give an indication of the structure of negotiation skills: by resorting either to a number of manipulative techniques or to open, unambiguous communication. At the same time, it would be utopian to assume that people only play fair and, as Lewicki and Robinson claim, behaviour that is not entirely honest and open can nevertheless determine the effectiveness of negotiation (Lewicki and Robinson, 1998). Moreover, Kowalczyk (2001) in her empirical study shows that an effective negotiator uses a mixed approach that involves both assertiveness (i.e., openness) and submissiveness in communication, thus minimizing aggressiveness in communication. In addition, Kowalczyk (2001) claims that the effectiveness of negotiation is also determined by the ability to detect errors in communicated messages. Moreover, not all behaviour based on withholding the truth is equally condemned in public perception. The literature presents a number of studies on the perception of such behaviour and its determinants (e.g., resulting from particular cultural, gender, social and professional positions).

Communication in negotiation involves an alternating exchange of information, in which one must strike a balance between extreme reactivity and extreme autonomy. The first option would mean complete submission to the other party, whereby one becomes a puppet who is led solely by others and cannot express one's own opinions. The second option would mean total independence from the counterparty: the negotiator refuses to match one's own reaction to what the other party says. In other words, the parties are on different wavelengths (Stewart, 2005). In negotiation, it is especially important to balance one's position: to listen to others, react to what they communicate and propose new, previously unmentioned ideas. Effective negotiation is often identified with skilful persuasion, which depends on the construction of arguments, message structure and the style of persuasion (i.e., the central route of persuasion), as well as the context in which the talks take place and the charisma of the negotiator (i.e., the peripheral route of persuasion). When interactions occur via the central route, one can expect a long-lasting and relatively resilient new attitude to be established, whereas in the case of the peripheral route, the effect is short-lived and vulnerable to contrary aims set by the other party (Lewicki, Saunders, Barry and Minton, 2005). However, Donaldson and Donaldson (1999) note that skilful listening opens the way to success. Active listening is a mean to extract valuable information from an interlocutor and to share one's own thoughts (e.g., Fisher and Brown, 2010). Unfortunately, empirical research conducted by Nichols and Stevens (1957, cited in Stewart, 2005) shows that children lose the ability to listen with age. First-grade school children were able to repeat correctly $90 \%$ of the content taught by a teacher, whereas for second-grade pupils it was $80 \%$, and for high school graduates as little as $28 \%$. On the one hand, it is natural for people to listen; however, an influx of stimuli can hinder perception and memory, and therefore training is necessary in this field. Active listening is also based on skilful questioning, in particular the use of open questions (e.g., Lewicki et al., 2006; Donaldson and Donaldson, 1999; Chełpa, 2000). These are helpful in obtaining information that can be of advantage at the negotiating table (Lewicki et al., 2006), although as Brodt notices (1994, cited in Lewicki et al., 2006), this approach can sometimes weaken the other party, especially when they limit themselves under the influence of the perceived advantage of the counterparty. Brodt refers to this situation as 'the information-is-weakness effect'.

Another key tool of active listening is to check whether one has understood the meaning of what one has heard, by paraphrasing statements uttered by the bargainer and asking for 
details. Ethical behaviour based on open communication leads to a more extensive sharing of valid information, increasing the probability of reaching a better agreement (Fleck et al., 2014). The above-mentioned types of communication behaviour build communication competence based on assertive exchange. These findings have been used to construct the first dimension of a questionnaire that describes communication behaviour in negotiation, called 'open communication' (OC).

A tendency to use manipulative techniques (MT) in negotiation can be considered the second dimension of communication. No matter how much we want negotiation to be based on the principles of fair play, it will always include some poker tricks. Numerous studies have shown that unethical behaviour is not a rarity. It has been proved that $28 \%$ of negotiators habitually employ misrepresentation, $25 \%$ of retailers do not fully communicate the true information about their products, whereas more than $60 \%$ of entrepreneurs rely upon building false images of their companies (Fleck et al., 2014). A study conducted in Poland shows that $48 \%$ of professional negotiators use manipulation in response to manipulation, $22 \%$ use it when there is no other method and only $22 \%$ consider it to be unacceptable (Jastrzębska-Smolaga, 2007). Research on the ethics of negotiation has been conducted by a large group of researchers. Lewicki and Robinson (1989) have concluded that a certain amount of ethically ambiguous behaviour can improve and determine the effectiveness of negotiation. The aim of misrepresentation in negotiation, which is frequently used by negotiating parties, is to build the strength of the lying party. In addition, due to the distributive nature of negotiation, negotiating parties feel that they are allowed to resort to ethically dubious methods (Garcia, Darley and Robinson, 2001). At the same time, classification of manipulative behaviour is very diverse. The above-mentioned authors classify it as follows (Lewicki and Robinson, 1989):

1 Misrepresentation of position to an opponent. The negotiator distorts his or her preferred settlement point. For example, a candidate for a job may say that he or she can only accept a salary of 1,000 euros, when in fact he or she is willing to accept 800 euros. This wellknown technique of masking the settlement point is characteristic of hard negotiation (Fisher, Ury and Patton, 1994).

Bluffing. The negotiator makes false promises or false threats that may involve describing $\angle$ positive or negative consequences which are conditional on the other party's behaviour (e.g., if I do not get a pay rise, I will quit the job).

3 Falsification. The negotiator introduces erroneous information into the discussion, in or3 der to change the opponent's position. Employees may provide information about work offers that they have allegedly received. They may also submit false certificates confirming their competence.

Deception. The negotiator attempts to manipulate the opponent's logical and inferential 4 processes in order to lead him or her to false conclusions. This can be done by telling half-truths and claiming that this is all one might say in this case. For example, job candidates may not disclose all the reasons for which they parted ways with their previous employers.

5 Selective disclosure or misrepresentation to constituencies. The negotiator may misrep5 resent the other party's expectations to their constituencies in order to justify his or her choices and decisions.

In his study on the acceptance of using manipulative tactics, Anton found that the misrepresentation of one's position was recognized as the most ethical method, followed by bluffing (considered to be the most neutral behaviour), whereas deception and falsification were defi- 
nitely considered unethical. Based on the SINS scale (Self-reported Inappropriate Negotiation Strategies), it was also found that individual techniques were perceived as ethical or unethical depending on national culture (US citizens were more tolerant than non-US citizens), sex (men looked more favourably on these techniques) and attitude towards aggressive and cooperative strategies (supporters of the former were more tolerant of manipulative behaviour) (Lewicki and Robinson, 1998). The acceptance of manipulative techniques is also affected by the cultural dimension described by Hofstede as 'collectivism-individualism'. For members of collectivist societies, lying for the sake of a group may manifest the fulfilment of collective obligations, whereas negotiators from individualistic cultures are less likely to use deception, because there is no pressure imposed by such rules in these societies (Zhang, Liu and Liu, 2012).

Even though manipulative techniques are perceived as unethical, they are still quite commonly used (Lewicki and Hanke, 2012). In the context of the trilateral (relational) communication model, Kowalczyk (2013) has divided manipulative tactics into those that manipulate the negotiator's own image (e.g., positive self-presentation, self-blame, incomplete competence, relaying, self-deprecation), those that manipulate the counterparty (e.g., compliments, personal attacks, threats, good guy/bad guy tactics, mood swings) and those that manipulate the subject of communication (e.g., bluffing, nibbling, poker tactics, 'reward in paradise', 'the vice', flattery, postponing issues, aiming high, 'funny money', compromise, slow concessions, silence, 'splitting the difference'). Studies on the use of these tactics during job negotiations show that job candidates frequently use positive self-presentation, aiming high and slow concessions. Candidates dare to use these tactics because recruiters permit them to take up the game; they then split the difference, make a compromise or ask for a better offer (Kowalczyk, 2011). In contrast, other people avoid these techniques for fear of being unmasked and having sanctions imposed on them, or if they prefer a cooperative strategy. These findings form the basis for the second dimension of the negotiation behaviour questionnaire, which measures the propensity to use manipulative techniques.

\section{Social value orientation, experience and satisfaction in negotiation}

Among the different ways of analysing a negotiation situation, special attention should be paid to the theory of games developed in the late 1920s and 1930s by von Neumann, Borel and Morgenster. Afterwards the game theory has been used for the analysis of negotiations by Nash, Douglas, Raiffa and Shubik, among others (Kowalczyk, 2001). The analysis of players' behaviour made it possible to formulate the concept of social value orientation, shaped by a two-dimensional structure of social space that determines how much weight a person attaches to his or her own outcomes in relation to those of the interaction partners (Mazur, 2002; van Lange, Bekkers, Schuyt and van Vugt, 2007; Grzelak, 2004). As a result, nine different orientations have been distinguished. In the context of this study, special attention will be paid to three of them: cooperation, individualism and competition. All of these are characterized by a positive attitude towards one's own results, alongside different attitudes to the other party's outcome (from positive, through neutral, to negative).

The mottos of people with these orientations can be summarized as follows: cooperators - I want us to win; individualists - I want to win; and competitors - I want to win against you. Numerous studies of social value orientation have shown that it changes under the influence of environmental factors, such as game instructions, the availability and type of information about the other party, the possibility of communication, and what is at stake in the game. In addition, competition is strongly associated with the zero-sum game or the distributive strategy, which is based on the idea of having to compete for scarce goods. In contrast, co- 
operation is linked to the logic of the non-zero-sum game and assumes that the two parties can gain more by cooperating and leading integrative negotiations (Lewicki et al., 2006), as was seen by Fisher, Ury and Patton (1996), the creators of the fair play negotiation principles. The third strategy - individualism - perceives victory in negotiation in absolute terms. While two of these aforementioned orientations - competitive and individualistic - can be regarded as 'proself', the cooperative orientation should be regarded as 'prosocial'.

On the one hand, negotiation strategies are conditioned by internal preferences (e.g., personality traits); on the other hand, they are subject to environmental modifications, which may cause the negotiators either to act in harmony with themselves, or to feel uncomfortable, i.e. to experience post-negotiation dissonance effect. While deliberately ignoring the issue of external influences, it is worth noting that personality traits are a strong determinant of social value orientation. They are built up from early childhood and shape the way an individual deals with social dilemmas (Bogaert, Boone and Declerck, 2008). Various sources indicate that empathy, a sense of responsibility, self-perception, the ability to assist others and a belief in the justice of the world are particularly conducive to the prosocial orientation (McCullough and Tabak, 2010). In her study, Kowalczyk (2004) also shows that emotional intelligence is correlated with the cooperative approach, by considering a game developed on the basis of 'The Prisoner's Dilemma' and entitled 'The Candidate's Dilemma'.

In addition, many of the researchers who refer to the Eysenckian tradition have successfully sought the biological substrates of social value orientation. Modern research has confirmed their intuitions, arguing that the characteristics responsible for the prosocial orientation such as trust, empathy, cooperation and altruism - have a genetic component, which explains $40-70 \%$ of the prosocial variance in adults' preferences. Factors that are responsible for this phenomenon include dopamine receptor polymorphism and the genetic diversity of the structures of vasopressin and oxytocin receptors, among others (McCullough and Tabak, 2010).

As personality and genetic factors determine the stability of social value orientation (Bogaert et al., 2008), the intention in the empirical part of the study was to investigate whether the prosocial and proself orientations are correlated with a tendency to resort to openness and manipulation in negotiation. Transferring the study from the laboratory space to a virtual portal determined the orientation measurement method, which is described in the empirical section of this article.

_ Hypothesis 1: There is a correlation between social value orientation and the use of manipulation-based and open communication in negotiation.

Assuming that practice makes perfect, it is also worth noting that experience in negotiation affects the adoption of different types of negotiation behaviour (Lewicki et al., 2006), whether they are based on manipulation or open communication. In their experiment, $\mathrm{Ne}-$ ale and Northcraft simulated a selling and buying negotiation, in which they compared the results of amateurs (students and graduates) with those of negotiators with at least ten years of experience. They found that both groups tried to negotiate integratively, but the experts were more integrative at the beginning of negotiation than amateurs, and their results were slightly better than those of the amateurs. In contrast, other research suggests that experience reduces the likelihood of using less ethical negotiation techniques (Lewicki et al., 2006). The literature provides many examples of the impact of experience on the effect of negotiation, and researchers are of the opinion that it positively affects the cognitive and behavioural performance. It builds the knowledge and skills that are the basis 
of negotiation competence (Mintu-Wimsatt and Gassenheimer, 2000). Kowalczyk (2001) has reached a similar conclusion, arguing on the basis of empirical research that the frequency of negotiation increases its efficiency, but this factor has little effect on the methodology of the negotiating procedure, i.e., the way in which goals are formulated. Since it is difficult to improve the latter in practice, issues related to identifying and pursuing objectives should be incorporated into training programmes.

_ Hypothesis $2 a$ : There is a correlation between the frequency of negotiation and communication based on manipulative techniques

_ Hypothesis $2 b$ : There is a correlation between the frequency of negotiation and open communication

Perceived satisfaction with negotiation is the last issue to be investigated in this paper. Satisfaction can be understood as an emotional state attained after reaching a target (Reber, 2000). However, in the context of negotiation, satisfaction can be understood as an affective state associated with the assessment of a reached agreement. Research on satisfaction is important insofar as its achievement (or non-achievement) affects further relations between the parties (Oliver et al., 1994). Nowadays, companies that outsource specialized services do not resort to one-off negotiations, but prefer long-term cooperation with service providers. In this context, satisfaction with negotiation proves a very significant factor in helping to build relationships.

In their study of satisfaction in negotiation, Stöckli and Tanner (2014) came to the conclusion that, contrary to popular belief, integrative negotiation is not always more satisfying than distributive negotiation. This is affected by the type of negotiation: value-based (e.g., morality, fairness, justness, honour, honesty) or interest-based (e.g., pay, promotion, career, selling-buying negotiation). They proved that, in value-based negotiation, there is less of a tendency to make concessions and distributive negotiation gives more satisfaction, while in interest-based negotiation, greater satisfaction is achieved from the integrative settlement of disputes. Furthermore, in accordance with Oliver, Balakrishnan and Barry (1994), the comparison of desired goals with achieved goals triggers a subjectively perceived satisfaction or dissatisfaction with the negotiation. It should be noted that the tendency to feel satisfied with a particular negotiation outcome might be conditioned by the negotiating method used to achieve this goal. Some people do not feel complete satisfaction when the means they have used were, in their opinion, inadequate to the situation (Winch and Winch, 2005, p. 27).

Finally, resorting to manipulative techniques that do not comply with standards (i.e., that are not quite acceptable) can lead to the post-negotiation dissonance effect. In such circumstances, persons may obtain even better objective results, but their subjective account of ethical profit and loss nevertheless leads to discomfort, which is a manifestation of the post-negotiation dissonance effect. It can be assumed that this effect does not appear when using open, assertive communication. At the same time, satisfactory negotiation outcomes can be analysed, among other ways, in terms of (a) implementation of substantive goals, (b) creation of relationships, and (c) overall satisfaction.

_ Hypothesis 3a: There is a correlation between satisfaction with the implementation of substantive goals, the creation of relationships and overall satisfaction, and negotiation based on open communication.

_ Hypothesis 3b: The use of manipulative negotiation techniques reduces perceived satisfaction, which is a manifestation of the post-negotiation dissonance effect. 


\section{Research methodology}

\section{Description of the studied group}

The study was carried out in the second and third quarter of 2013 , through the website: ebadania.pl. The questionnaire was filled in by 313 respondents, including 204 (65.2\%) women and $109(34.8 \%)$ men. The average age of the group was $31.8 \pm 7.62$ years and did not differ between the sexes $(t(204)=-0.49, p=0.627)$. The youngest woman and man were each 22 years old, while the oldest subjects were 56 and 61, respectively.

The analysis involved working people. The average length of service of respondents was $9.6 \pm 7.27$ years and did not differ significantly between men and women $(\mathrm{t}(195)=-0.97$, $p=0.333$ ). Table 1 presents a detailed frequency distribution of respondents.

\begin{tabular}{|c|c|c|c|}
\hline & Characteristics of respondents & $\mathrm{N}$ & $\%$ \\
\hline \multirow{5}{*}{ 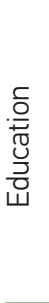 } & Secondary & 7 & 2.2 \\
\hline & Undergraduate/Engineering & 82 & 26.2 \\
\hline & MA & 124 & 39.6 \\
\hline & Postgraduate & 94 & 30.0 \\
\hline & PhD and higher & 6 & 1.9 \\
\hline \multirow{5}{*}{ 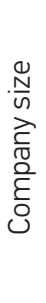 } & From 1 to 9 employees & 53 & 16.9 \\
\hline & From 10 to 49 employees & 68 & 21.7 \\
\hline & From 50 to 249 employees & 75 & 24.0 \\
\hline & From 250 to 999 employees & 48 & 15.3 \\
\hline & More than 1000 employees & 66 & 21.1 \\
\hline \multirow{5}{*}{ 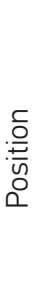 } & & $\mathrm{N}$ (Women, Men) & $\%$ (Women, Men) \\
\hline & Senior managerial & $60(29 ; 31)$ & $19.2(14.2 ; 28.4)$ \\
\hline & Junior managerial & $63(34 ; 29)$ & $20.1(16.7 ; 26.6)$ \\
\hline & Independent/Specialist & $146(106 ; 40)$ & $46.6(52 ; 36.7)$ \\
\hline & Entry-level & $44(35 ; 9)$ & $14.1(17.2 ; 8.3)$ \\
\hline
\end{tabular}

As the presented data show, most of the respondents had a master's degree. In addition, the analysis did not reveal differences in education between men and women ( $W=10806$, $z=0.43, p=0.666)$. In contrast, differences were found in their respective positions within the workplace $\left(\mathrm{chi}^{2}(3)=18.54, \mathrm{p}<0.001\right)$. It has been shown that women rarely occupy managerial positions and are more often found in independent/specialist or entry-level positions. This corresponds to other data concerning difficulties faced by women on their way to vertical promotion. Sex did not correlate with the size of the company in which respondents were employed $\left(\operatorname{chi}^{2}(5)=7.64, \mathrm{p}=0.177\right)$.

\section{An empirical study on the determinants of communication in negotiation}

Table 1

Characteristics of respondents by education, position and the size of the organization in which they work 


\section{Table 2}

Descriptive statistics of the distribution of results in the studied group

\begin{tabular}{l|c|c|c|c} 
& mean & sd & median & se \\
\hline \multicolumn{5}{c}{ Women $(\mathrm{N}=204)$} \\
\hline MT & 20.43 & 5.025 & 21 & 0.352 \\
\hline OC & 31.91 & 3.638 & 32 & 0.255 \\
\hline \multicolumn{5}{c}{ Men (N=109) } \\
\hline MT & 21.50 & 5.579 & 21 & 0.534 \\
\hline OC & 31.05 & 4.408 & 32 & 0.422 \\
\hline
\end{tabular}
was based on the factor analysis, which resulted in eight selected items making up each of the scales.

Each respondent could receive between one and five points for each item, reflecting the significance of characteristics investigated by a given scale. Therefore, theoretical scores ranged from eight to 40 points. The obtained values are presented in Table 2.

\section{Selected psychological determinants and consequences of the use of negotiation skills and techniques}

\section{Social value orientation and communication behaviour of negotiators}

The first research problem concerned the correlation between communication skills, the use of negotiation techniques and social value orientation. Proself and prosocial orientations were determined based on self-evaluation made on two five-category scales, in which respondents declared which negotiation outcomes were most important for them. The goals pursued by negotiators depending on their social value orientations, which enabled Hypothesis 1 to be tested, are presented in Table 3.

Based on the choices made by respondents, three groups were distinguished: a group of 236 individuals with a prosocial orientation, a group of 52 individuals with a proself orientation and 25 individuals presenting a mixed approach. The last group was omitted in the further analysis.

Table 3

Approach to goals as the basis for diagnosing prosocial orientation

\begin{tabular}{|c|c|c|c|}
\hline & Goals pursued by negotiators & $\begin{array}{c}\text { Proself } \\
\text { orientation }\end{array}$ & $\begin{array}{l}\text { Prosocial } \\
\text { orientation }\end{array}$ \\
\hline \multirow{5}{*}{ 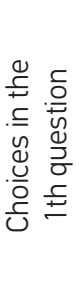 } & I win and the other party loses. & 17 & 0 \\
\hline & I win and the other party's outcomes are not important. & 35 & 0 \\
\hline & The other party wins and my outcomes are less important. & 0 & 2 \\
\hline & Both parties win but each must make a compromise. & 0 & 31 \\
\hline & Both parties win and can fulfil their respective interests in negotiation. & 0 & 203 \\
\hline \multirow{5}{*}{ 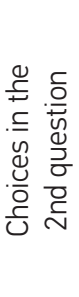 } & Both parties lose the least. & 1 & 25 \\
\hline & Both parties reach similar outcomes. & 1 & 28 \\
\hline & Both parties achieve the most. & 7 & 174 \\
\hline & My outcomes are better than those of the other party. & 26 & 0 \\
\hline & My outcomes are not worse than those of the other party. & 17 & 9 \\
\hline
\end{tabular}


The analysis of the use of manipulative techniques showed that persons with a proself orientation had higher scores ( $W=8330.5, z=4.04, p<0.001, d=0.58$ [0.27 - 0.88]), meaning that self-focus is often associated with ethically ambiguous negotiation methods. As for the open communication variable, the difference based on orientation was not so clear $(d=-0.39$ [-0.7 - -0.09]), but still significant $(W=5044.00, z=2.01, p=0.044)$. In this case, the higher the use of fair communication, the greater the prosocial tendency. The analysis made it possible to accept Hypothesis 1, which assumes a correlation between social value orientation and the relative use of manipulation and open communication in negotiation.

\section{The frequency of negotiation as a determinant of the use of manipulative techniques and open communication}

As earlier research shows, the factor that affects the type and quality of an individual's negotiation skills is experience, measured as the frequency of both business negotiations, i.e., those settled by superiors within an organization, and non-business negotiations, which affect the quality of personal life.

For the purposes of this study, frequency of negotiation was measured in orderly intervals (more than 100 per year, 50100 times/year; $12-50$ times/ year; 8-12 times/year; 4-8 times/year; less often; never) in order to analyse its impact on scores on the MT and OC scales, using a Spearman's rank correlation coefficient.

The presented data show that the frequency of both business and non-business negotiations affects the frequency of the use of manipulative techniques. This correlation can be estimated at around 4\%. What prevents people from using these techniques is the fear of being unmasked and a lack of confidence, but the aforementioned obstacles can be eliminated through negotiating experience. In contrast, open communication is not conditioned by negotiating experience, which may be related to the fact that this skill is not specific to negotiation and can be developed in many other situations. This analysis demonstrates that Hypothesis 2a, which describes a correlation between the frequency of negotiation and communication based on manipulative techniques, can be ac-

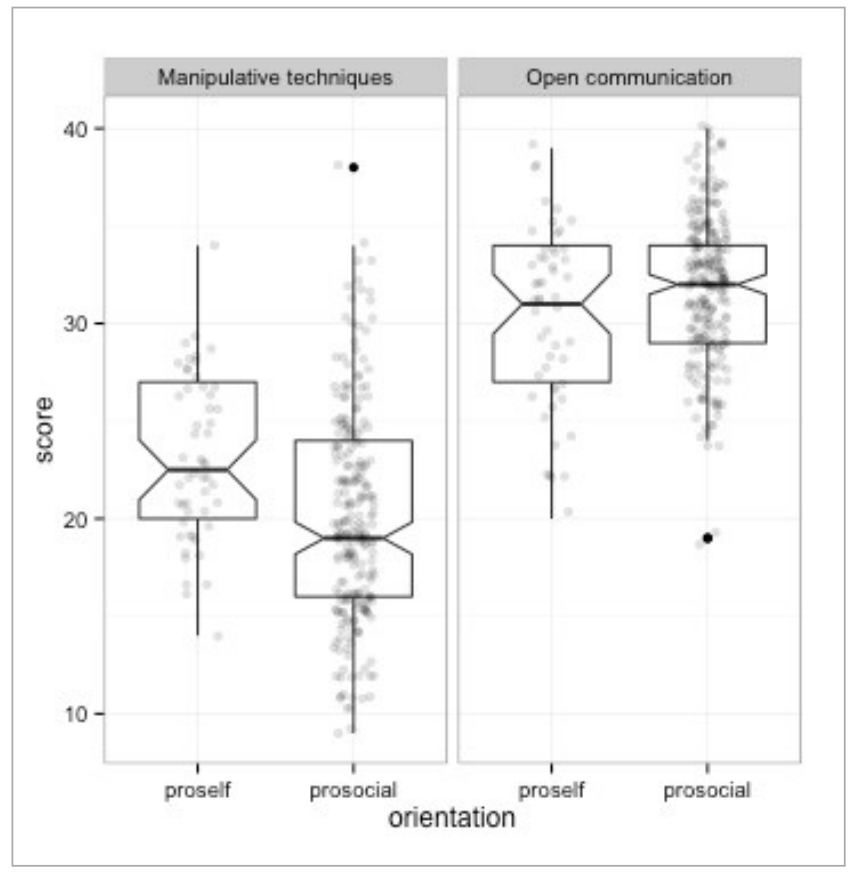

\begin{tabular}{l|c|c|c|c} 
& \multicolumn{2}{|c|}{ Manipulative techniques } & \multicolumn{2}{c}{ Open communication } \\
\hline & rho & $p$ & rho & $p$ \\
\hline FB & 0.22 & $<0.001$ & 0.10 & 0.067 \\
\hline FnB & 0.22 & $<0.001$ & 0.08 & 0.174 \\
\hline
\end{tabular}

Note FB - frequencies of business negotiations;

$\mathrm{FnB}$ - frequencies of non-business negotiations.
Figure 1

Distribution of scores on the MT and OC scales depending on social value orientation
Table 4

Correlation coefficients between scores on the MT and OC scales, and the frequency of negotiations 
Figure 2

Distribution of scores on depending on the type of frequency of negotiations the MT and OC scales,

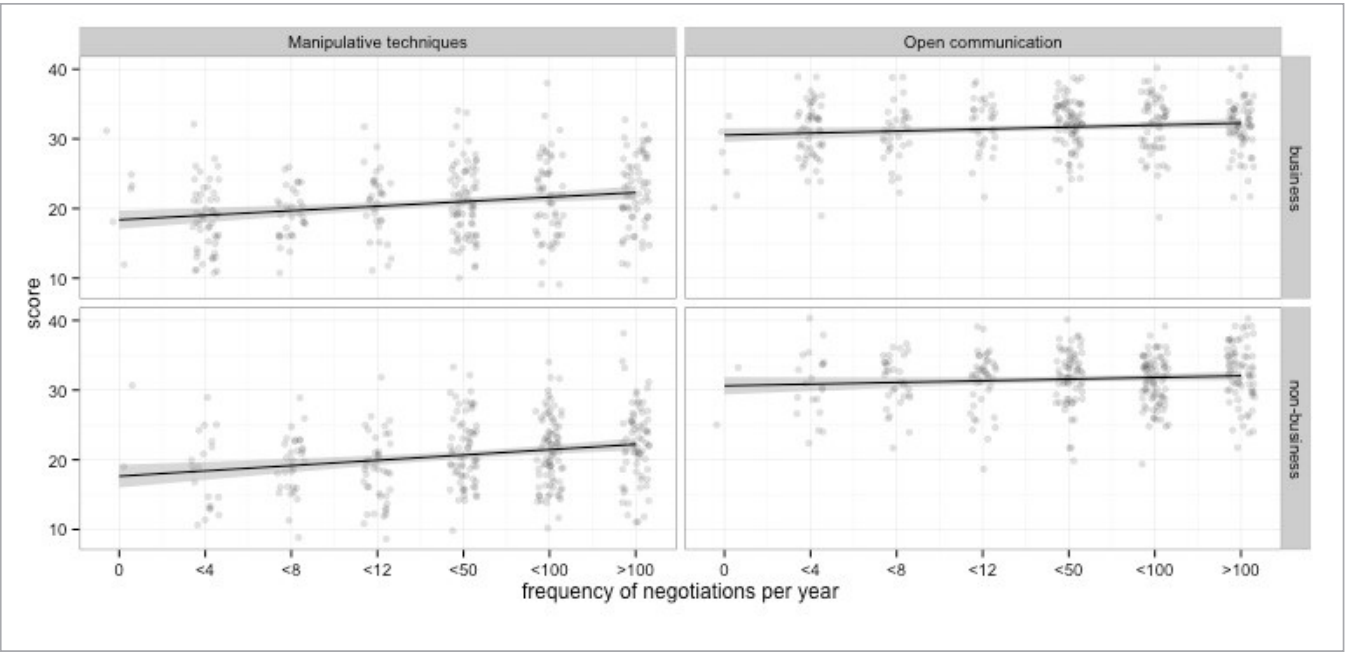

cepted. Perhaps, persons who often negotiated improved their skills and they are more confident, and they are less apprehension of unpleasant consequences.

In contrast, Hypothesis $2 b$, which assumes a correlation between the frequency of negotiation and the use of open communication, has not been confirmed. We can explain this result, the this type of communication could be improved in different social situations, and thereby the no-negotiators could be also proficient in the use of it.

\section{Satisfaction and scores on the MT and OC scales. Post-negotiation dissonance effect}

The final issue analysed in this article is the question of whether the relative use of manipulative techniques and open communication in negotiation affects the negotiator's declared satisfaction with the negotiation. Overall satisfaction has been divided into a) satisfaction with achieved negotiation goals, b) satisfaction with interpersonal relationships and was measured on a five-point scale, but since respondents mainly chose either category 2 (low satisfaction) or category 4 (high satisfaction), responses were divided into two categories: low or high satisfaction.

The analysis of results conducted using a non-parametric Wilcoxon test shows that open communication differs depending on the perceived level of satisfaction. People with higher satisfaction have significantly higher scores on the $\mathrm{OC}$ scale (by satisfaction with achieved negotiation goals: $W=7604, z=3.96, p<0.001$; by satisfaction with relationships: $W=8951$, $z=2.21, p=0.027$; by overall satisfaction: $W=7211, z=3.91, p<0.001)$. It therefore follows

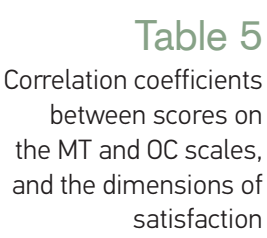

\begin{tabular}{l|c|c|c|c} 
& \multicolumn{2}{|c|}{ Manipulative techniques } & \multicolumn{2}{c}{ Open communication } \\
\hline & rho & $p$ & rho & $p$ \\
\hline SWN & 0.09 & 0.101 & 0.26 & $<0.001$ \\
\hline SWR & -0.04 & 0.499 & 0.18 & 0.02 \\
\hline OS & 0.11 & 0.044 & 0.22 & $<0.001$ \\
\hline
\end{tabular}

that open, assertive communication promotes a sense of satisfaction with both the substantive results and the relationships developed during negotiation. The effect size for the difference is expressed as a Cohen's d coefficient, and equals $d[95 \% \mathrm{Cl}]=-0.5[-0.75$, $-0.25]$. Respondents with different levels of satisfaction did not differ in the category 
of manipulative techniques (by satisfaction with achieved negotiation goals: $W=10085, z=$ $0.61, p=0.544$; by satisfaction with relationships: $\mathrm{W}=11246$, $z=0.88, p=0.380$; by overall satisfaction: $\mathrm{W}=9129.5, \mathrm{z}=$ $1.25, p=0.211)$. This shows that, while the use of not entirely honest methods may be effective, the feeling of not being completely fair neutralizes any satisfaction perceived by negotiators, an effect of which has been termed the post-negotiation dissonance effect.

Both remaining hypotheses have consequently been accepted: Hypothesis 3a, which assumes a correlation between satisfaction with achieved negotiation goals, interpersonal relationships and overall satisfaction, and behaviour based on open communication; and Hypothesis 3b, which states that the use of manipulative techniques neutralizes perceived satisfaction, which is evidence of the post-negotiation dissonance effect.

Summing up the study, we can formulate a number of general conclusions that are presented below.

The main research conclusions related with the dimension of open communication are:

1 Prosocial orientation is more often accompanied by open communication.

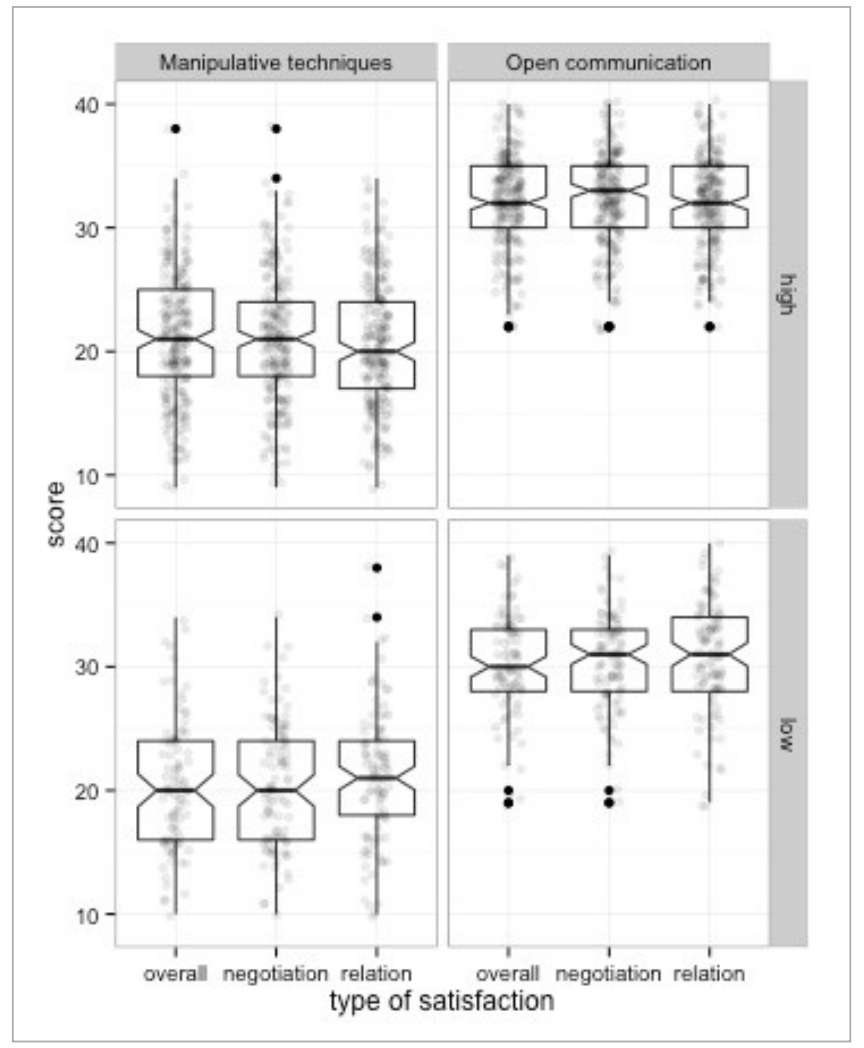

Figure 3

The use of manipulative techniques and open communication depending on the level of satisfaction

While the recall to manipulative techniques may be put off by such research findings as:

$1 \begin{aligned} & \text { Proself orientation is } 2 \begin{array}{l}\text { The more experience, } \\ \text { more often accompa- }\end{array} \text { the more manipulation. }\end{aligned}$ nied by manipulation.

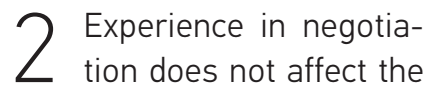
use of open communication.
3 The more openness satisfaction with achieved goals, relationships and overall satisfaction.
3 Due to the post-negotiskills in the use of manipulative techniques do not increase satisfaction with negotiation. 
Finally, we can note that two dimensions of communication are conditioned by such selected factors, as social value orientation, experience and satisfaction in negotiation.

It should be emphasized that, despite the ethical ambiguity of manipulation and its related discomforts, such methods will remain in use in negotiation practice for the foreseeable future. Nonetheless, the importance of open communication in negotiation, and its potential benefits, are also worth emphasizing.

\section{References}

Bogaert S., Boone C., \&Declerck C. (2008). Social value orientation and cooperation in social dilemas: A review and conceptual model, British Journal of Social Psychology, 47, 453-480. http:// dx.doi.org/10.1348/014466607X244970

Chełpa S. (2000). Negocjacje w biznesie. Kluczowe zagadnienia. Poznań: Wydawnictwo Terra.

Donaldson M.C., \& Donaldson M. (1999). Negocjacje (Negotiation for Dummies). Warszawa: Wydawnictwo RM.

Fleck D., Volkema R., Pereira S., Levy B., \& Vaccari L. (2014). Neutralizing Unethical Negotiating Tactics: An Empirical Investigation of Approach Selection and Effectiveness, Negotiation Journal, 1, 23-48. http://dx.doi.org/10.1111/nejo.12044

Fisher R., \& Brown S. (2010). Nietoksyczne negocjacje (Getting Together: Building a Relationship The Gets to Yes). Gliwice: Helion.

Fisher R., Ury W., \& Patton B. (1994). Dochodząc do Tak. Negocjowanie bez poddawania się (Getting to YES. Negotiation Agreement Without Giving In), Warszawa: PWE.

Garcia S.M., Darley J.M., \& Robinson R.J. (2001), Morally Questionable Negotiations Between District Attorneys and Public Defenders. Personality and Social Psychology Bulletin, 27, 731-743, downloaded from http://psp.sagepup.com, 27.03.2015. http://dx.doi.org/10.1177/0146167201276008

Grzelak J. Ł. (2004). Dylematy społeczne. In T. Tyszka (Ed.), Psychologia ekonomiczna (pp. 243276). Gdańsk: GWP.

Jastrzębska-Smolaga H. (Ed.). (2007). Ekonomiczne podstawy negocjacji. Warszawa: Difin.

Kowalczyk E. (2013), Manipulacje komunikacją interpersonalną w procesie negocjacji (Manipulation of interpersonal communication in the negotiation proces). Acta Universitatis Lodziensis, Folia Oeconomica 282, 147-158.

Kowalczyk E. (2011). Proces negocjacji w sprawie pracy. Aspekty psychospoteczne i organizacyjne.
Poznań: Wydawnictwo Uniwersytetu Ekonomicznego w Poznaniu.

Kowalczyk E. (2004), Teoria gier, inteligencja emocjonalna a kryzys na rynku pracy. Zeszyty Naukowe Akademii Ekonomicznej w Poznaniu, 50, 239-249.

Kowalczyk E. (2001). Psychospołeczne uwarunkowania negocjacji gospodarczych (Psychosocial conditioning of business negotiations). Poznań: Wydawnictwo Akademii Ekonomicznej w Poznaniu.

Lange P.A.M. van, Bekkers R., Schuyt T.N., \& Vugt M. van (2007). From Games to Giving: Social Value Orientation Predicts Donations to Noble Causes. Basic and Applied Social Psychology, 29(4), 375-384. http://dx.doi. org/10.1080/01973530701665223

Lewicki R.J., \& Hanke R. (2012). Once Fooled, Shame on You! Twice Fooled, Shame on Me! What Deception Does to Deceivers and Victims: Implications for Negotiators When Ethically Is Unclear. In: B.M. Goldman, D.L. Shapiro (Eds.), The Psychology of Negotiations in the 21 st Century Workplace, (pp. 211-241). New York - London: Routlegde.

Lewicki R.J., Saunders D.M., \& Barry B. (2006). Negotiation, (5th ed.). International Edition: McGraw-Hill.

Lewicki R.L., Saunders D.M., Barry B., \& Minton J.W. (2005). Zasady negocjacji. Kompendium wiedzy dla trenerów i menedżerów (Essentials of Negotiation. Third edition), Poznań: Dom Wydawniczy Rebis,

Lewicki R.J., \& Robinson R.J. (1998). Ethical and Unethical Bargaining Tactics: An Empirical Study. Journal of Business Ethics 17, 665-682.

Mazur M. (2002). Orientacje społeczne (Social orientations). In: M. Lewicka, J. Grzelak (Eds.) Jednostka i spoteczeńswto. Podejście psychologiczne (pp.117-130). Gdańsk: GWP, 2002,

McCullough M.E., \& Tabak B.A. (2010), Prosocial Behavior. In: R.F. Baumeister, \& E.J. Finkel (Eds.) 
Advanced Social Psychology. The state of the sciences (pp. 263-302). Oxford New York: Oxford University Press.

Mintu-Wimsatt A., \& Gassenheimer J.B. (2000). The Moderating Effects of Cultural Context in Buyer-Seller Negotiation. Journal of Personal Selling \& Sales Management, vol. XX, 1, 1-9.

Negocjacje (Guide to Negotiation) (2003). Konstancin-Jeziorna: MT Biznes Ltd..

Nęcki Z. (2000). Negocjacje w biznesie. Kraków: Antykwa.

Nierenberg G.I. (1994). Sztuka negocjacji jako metoda osiągania celów (The Art of Negotiating). Warszawa: Studio Emka.

Oliver R. L., Balakrishnan P.V. S. \& Barry B. (1994). Outcome Satisfaction in Negotiation: A test of Expectancy Discorfimation. Organizational Behavior and Human Decision Process, 60, 252275. http://dx.doi.org/10.1006/obhd.1994.1083

Reber A. S., (Ed). (2000). Stownik psychologii (The Pengium Dictionary of Psychology), Warszawa: Wydawnictwo Naukowe Scholar.
Rządca R.A., \& Wujec P. (1998). Negocjacje. Warszawa: Polskie Wydawnictwo Ekonomiczne.

Stewart J. (2005). Mosty zamiast murów. Podręcznik komunikacji interpersonalnej (Brigdes Not Walls. A Book about Interpersonal Communiction). Warszawa: Wydawnictwo Naukowe PWN.

Stöckli P.L., \& Tanner C. (2014). Are integrative or distributive outcomes more satisfactory? The effects of interest-based versus value-based issues on negotiator satisfaction. European Journal of Social Psychology, 44, 202-208. http://dx.doi. org/10.1002/ejsp.2003

Winch A., Winch S. (2005). Negocjacje. Jednostka, organizacja, kultura. Warszawa: Difin.

Zhang J., Liu L.A., \& Liu W. (2012, July), Does Trust Reduce Deception in Negotiation? Culturally Divergent Effect of Cognition-based and Affectbased Trust, Paper presented at the 25th Annual International Association of Conflict Management Conference in Spier, South-Africa. http://dx.doi org/10.2139/ssrn.2084879

\section{Elżbieta Kowalczyk, Paweł Kleka. Tarpasmeninès komunikacijos veiksniai derybų metu: tarp atvirumo ir manipuliacijos}

\section{Santrauka}

Straipsnyje analizuojamos problemos, susijusios su dviem derybu komunikacijos dimensijomis. Autoriai empiriškai tyrè tokius veiksnius kaip socialinès vertès orientacija, derybu patirtis ir pasitenkinimas ja. Empirinio tyrimo klausimynas buvo patalpintas tinklalapyje ebadania.pl. Klausimyną užpilde 313 respondentų (65.2\% moteru ir $34.8 \%$ vyrų).

Egzistuoja daug derybų apibrèžimu, tačiau šis straipsnis remiasi apibrèžimu, kuri pasiūlè Fisher, Ury ir Patton (1994), manantys, kad derybos yra komunikacijos ir sprendimų prièmimo procesas, kuriame dalyvaujančios šalys siekia susitarimo tam tikru bendru klausimu. Autoriai daro prielaidą, kad komunikacijai būdingos dvi dimensijos: viena pagrįsta atviraja komunikacija, kita - manipuliacinèmis technikomis.

Pagrindiniai derybų komunikacijos aspektai yra šie:

_ Derybininkai turi surasti pusiausvyrą tarp reaktyvumo ir kraštutinès autonomijos. Derybose yra labai svarbu užimti tinkamą poziciją: klausytis kitų, reaguoti i jų pasiūlymus ir siūlyti naujas, dar neminètas idejjas (Stewart, 2005).

_ Derybos dažnai identifikuojamos su meistrišku įtikinèjimu, kuris priklauso nuo argumentų konstravimo, pranešimo struktūros ir įtikinejjimo stiliaus, taip pat konteksto, kuriame vyksta derybos, ir derybininko charizmos (Lewicki et al., 2005).

_ Meistriškas klausymasis derybose atveria kelią i sèkmę (Donaldson \& Donaldson 1999). Derybininkai turi išgauti iš pašnekovo vertingą informaciją ir pasidalinti savo mintimis (e.g., Fisher \& Brown, 2010) bei patikrinti, ar informacija buvo teisingai suprasta pateikiant teiginiu parafrazes ir prašant patikslinimo.

_ Etiškas elgesys, pagristas atviraja komunikacija, užtikrina ilgesni dalinimąsi validžia informacija ir didina galimybę pasiekti geresni susitarimą (Fleck et al., 2014). 
Manipuliacinių technikų naudojimo tendencija gali būti laikoma antraja komunikacijos dimensija. Yra irodyta, kad manipuliacines technikas derybininkai naudoja gana dažnai (Fleck et al., 2014). Nors manipuliacinès technikos laikomos neetiškomis, jos vis dar gana plačiai taikomos (Lewicki \& Hanke, 2012). Taip pat buvo nustatyta, kad tam tikros technikos vertinamos kaip etiškos ar neetiškos, priklausomai nuo nacionalinès kultūros, lyties ir požiūrio i agresyviąsias ir kooperacines strategijas (Lewicki \& Robinson, 1998; Zhang et al, 2012).

Remdamiesi išdèstytomis teorinèmis prielaidomis, autoriai parenge klausimyną, apimanti dvi skales: manipuliacinių technikų ir atvirosios komunikacijos. Skalių patikimumo koeficientai buvo patenkinami. Socialiniu vertybių orientacija. Daugelis socialinių vertybių orientaciją nagrinėjančių studiju parodè, kad ji kinta veikiama aplinkos veiksniu. Be to, konkurencija yra asocijuojama su distribucine strategija, kuri pagrista kovos už ribotus išteklius ideja. Priešingai, kooperacija pagrįsta prielaida, kad dvi šalys gali laimèti daugiau bendradarbiaudamos ir eidamos integracinių derybų keliu (Lewicki et al. 2006), kaip teigè sąžiningu derybų principu kūrèjai Fisher, Ury ir Patton (1996).

1 hipotezé: egzistuoja koreliacija tarp socialiniu vertybiu orientacijos ir manipuliacinès ar atvirosios komunikacijos taikymo derybose.

Remiantis respondentu atsakymais, buvo išskirtos šios grupės: 236 individai, pasižymintys orientacija i sociumą (kooperacinis žaidimas), 52 individai pasižymintys orientacija i save (konkurencinis žaidimas). Manipuliaciniu techniku taikymo analizè parodè, kad aukštesnius jverčius turi orientacija i save pasižymintys individai. Atvirosios komunikacijos kintamojo požiūriu orientacija pagristas skirtumas nebuvo toks aiškus, bet vis tiek reikšmingas. Remiantis analizès rezultatais, 1 hipotezè yra patvirtinta.

Patirtis. Laikantis prielaidos, kad kelias i tobulybę yra praktika, reikia pastebėti, kad patirtis derybose veikia skirtingu derybu elgesio tipu, pagristu manipuliacija ar atviraja komunikacija, pasirinkimą (Lewicki et al., 2006).

$2 a$ hipotezé: egzistuoja koreliacija tarp derybų dažnumo ir manipuliacinèmis technikomis pagristos komunikacijos.

$2 b$ hipotezé: egzistuoja koreliacija tarp derybų dažnumo ir atvirosios komunikacijos.

Derybų dažnumas buvo matuojamas reguliariais intervalais, siekiant ištirti jo poveiki manipuliacinių technikų ir atvirosios komunikacijos skalèms taikant Spearman'o ranginès koreliacijos koeficientą. Atlikta analizè parodè, kad $2 a$ hipotezè, apibūdinanti koreliaciją tarp derybu dažnumo ir manipuliacinèmis technikomis pagristos komunikacijos, yra patvirtinta; $2 b$ hipotezé dèl koreliacijos tarp derybų dažnumo ir atvirosios komunikacijos technikų taikymo nepasitvirtino. Atviroji komunikacija nèra nulemta derybinès patirties - šis gebejjimas nèra išskirtinis derybu sričiai ir gali būti ugdomas daugelyje kitu situacijų.

Pasitenkinimas. Stebimas pasitenkinimas derybomis yra paskutinis šiame straipsnyje nagrinèjamas aspektas. Derybų srityje pasitenkinimą galima traktuoti kaip emocinę būseną, siejamą su pasiekto susitarimo vertinimu. Pasitenkinimo tyrimai yra svarbūs tiek, kiek jo pasiekimas (ar nepasiekimas) veikia tolesnius šalių santykius (Oliver et al., 1994). Patenkinančius derybų rezultatus, be kitu būdų, galima analizuoti: (a) esminių tikslų pasiekimo, (b) ryšių sukūrimo ir (c) bendro pasitenkinimo požiūriais.

$3 a$ hipotezé: egzistuoja koreliacinis ryšys tarp pasitenkinimo ir esminių tikslų pasiekimo, ryšių sukūrimo, bendro pasitenkinimo ir atviraja komunikacija pagristų derybų.

3b hipotezé: manipuliacinių derybų technikų taikymas mažina stebimą pasitenkinimą - taip pasireiškia poderybinio disonanso poveikis (post-negotiation dissonance effect).

Empirinis tyrimas patvirtino, kad individai, kuriems būdingas didesnis pasitenkinimas, pasižymi žymiai aukštesniais jverčiais atvirosios komunikacijos skalejje. Todèl galima teigti, kad atviroji, asertyvi komunikacija skatina pasitenkinimo jausmą tiek derybu metu pasiektais esminiais rezultatais, tiek ir užmegztais ryšiais. Respondentai, kuriems būdingi skirtingi pasitenkinimo lygiai, nesiskyrè manipuliaciniu techniku kategorijoje. Tai rodo, kad nepaisant ne visai sąžiningu metodų taikymo efektyvumo, derybininkų nesąžiningumo jausmas neutralizuoja stebimą pasitenkinimą. Šis reiškinys vadinamas poderybinio disonanso poveikiu. Taigi abi pastarosios hipotezès pasitvirtino. 
Nepaisant manipuliacijos etinio dviprasmiškumo ir su juo susijusių sunkumu, manipuliaciniai metodai artimoje ateityje tebebus taikomi derybineje praktikoje. Tačiau verta atkreipti dèmesi ir $i$ atvirosios komunikacijos svarbą, ir potencialią naudą deryboms. Šio tyrimo rezultatai parodè, kad atvirają ir manipuliacinėmis technikomis grįstą dimensijas lemia socialinès vertès orientacija, patirtis ir pasitenkinimas derybomis.

REIKŠMINIAI ŽODŽIAI: komunikacija derybose, atviroji komunikacija, manipuliacinès technikos.

\section{ELŻBIETA KOWALCZYK}

Habilitated doctor in Economics (Management); Associate Professor

Poznań University of Economics, Poznań, Poland

Research interests

Negotiations, managerial and organizational psychology, management and development of human resources

\section{Address}

Aleja Niepodległości 10, 61-875 Poznań, Poland e.kowalczyk@ue.poznan.pl

\section{PAWEŁ KLEKA}

$\mathrm{PhD}$ in Social Sciences (Psychology), Assistant Professor

Adam Mickiewicz University, Poznan, Poland

\section{Research interests}

Methodology, scale construction, applied psychometrics, human-computer interaction, cognitive science and artificial thinking, science 2.0 and open access, virtual learning environments

\section{Address}

ul. Wieniawskiego 1, 60-712 Poznań, Poland

E-mail: pawel.kleka@amu.edu.pl

\section{About the authors}

